\title{
PENGARUH FAKTOR FUNDAMENTAL DAN RISIKOSISTEMATIK TERHADAP HARGA SAHAM DI PASARMODAL SYARIAH (STUDI EMPIRIS JII DI BEI TAHUN 2007-2010)
}

\author{
Fitri Aulianisa \\ Alumni Program Studi Ekonomi Islam, Fakultas Ilmu Agama Islam, Universitas Islam Indonesia \\ e-mail:arnesaku@gmail.com
}

\begin{abstract}
Abstrak
Penelitian ini menganalisa pengaruh faktor fundamental dan risiko sistemik terhadap harga saham delapan perusahaan yang terdaftar di Jakarta Islamic Index (JII) selama 2007-2010. Data dikumpulkan melalui studi pustaka dan pengumpulan data laporan keuangan. Regresi berganda digunakan untuk menganalisa pengaruh variabel independen terhadap variabel dependen dengan uji $t$ maupun uji $F$.Hasil penelitian menunjukkan bahwa hanya ROA dan NPM yang memiliki hubungan tidak searah dengan harga saham sedangkan variabel lainnya memiliki hubungan yang searah. Adapun uji parsial dengan derajat keyakinan 5\% menunjukkan hanya dua variabel yaitu EPS dan PER yang memiliki dampak signifikan terhadap harga saham dan variabel lainnya terbukti tidak memiliki dampak.
\end{abstract}

Kata Kunci: analisisfundamental, harga saham, faktor fundamental, risiko sistemik

\begin{abstract}
This research analyzed the effect of fundamental factors and systematic risk towards stock price of eight listed companiesinJakarta Islamic Index (JII) 2007-2010. The data was collectedby literature study and documentation of financial statements. Multiple regression is used to measure the effect of independent variable towards dependent variable along with ttest and $F$ test. The results based on overaal test suggested that only ROA and NPM hadopposite direction correlation with the stock price, meanwhile other variables hadpositive direction correlation. From partial test with 5\% level of significance,only EPS and PER had significanteffect on stock price while other variables had noeffect.
\end{abstract}

Keywords: fundamental analysis, stockprice, fundamental factor, systematic risk

\section{A. Latar Belakang}

\section{PENDAHULUAN}

Secara perlahan namun pasti, pasar modal telah tumbuh menjadi bagian penting dari pertumbuhan dan perkembangan perekonomian Indonesia. Sebagai negara yang tengah membangun dan mengejar ketertinggalannya dari negaranegara lain, maka faktor pembiayaan perusahaan merupakan salah satu factor penentu dan pasar modal diharapkan mampu menjadi alternatif pendanaan bagi perusahaan-perusahaan 
Indonesia disamping perbankan. Kehadiran pasar modal, pada sisi lainnya, dapat dilihat sebagai wahana dan alternatif dalam berinvestasi. ${ }^{1}$

Pasar modal menyediakan informasi yang dipublikasikan untuk kepentingan pada pelaku pasar (investor), yaitu dapat berupa informasi historical price, publikasi laporan keuangan perusahaan, informasi yang ada di laporan tahunan, dan kejadian-kejadian dalam perusahaan. Informasi-informasi yang dipublikasikan tersebut maupun informasi pribadi seringkali diperlukan investor dalam mengamati pergerakan harga saham dan melakukan transaksi jual beli saham dengan harapan untuk memperoleh return. ${ }^{2}$

Keinginan para investor untuk mendapatkan return yang besar ini membuat banyak investor melakukan banyak hal yang sebenarnya dilarang dan berpotensi mengacaukan ritme pasar yang seharusnya bisa berjalan secara efisien. Harga yang seharusnya mencerminkan nilai intrinsik dapat menipu sedemikan rupa akibat ulah investor nakal ini. Ketidakwajaran dalam fluktuasi harga yang tidak waras disebabkan oleh beberapa faktor, yang terutama dirujuk oleh Chapra adalah spekulasi yang didukung dengan margin trading. Para spekulan mencari keuntungan dari perbedaan harga dalam jangka pendek dan kerap kali mengabaikan prinsip bahwa tidak ada return tanpa risiko yang mengiringinya. Melakukan jual beli dari sesuatu yang tidak mereka konsumsi sendiri atau tidak mereka gunakan dalam usaha sendiri, tanpa suatu pekerjaan yang dilakukan dengan saham itu ataupun tidak ada nilai tambah yang diberikan, dan inilah yang acapkali disebut sebagai penyebab instabilitas keuangan. ${ }^{3}$

Seseorang dianggap spekulatif apabila ia ditengarai memiliki motifmemanfaatkan ketidakpastian tersebut untuk keuntungan jangka pendek.Sedangkan true investor tidak berniat dan atau terlibat dalam perdagangan jangkapendek, karena "the shorter the time the security in intended to be held, the lessstrong is the investment motive". Niat investor, setidaknya pada saat pembelianadalah untuk memegang saham dalam jangka panjang. Niat menjadi sangatpenting sebagai aspek normatif di sini, karena setiap perbuatan bergantung padaniat. Mereka akan tetap digolongkan investor jika pertimbangan perubahankeputusannya adalah faktor rasional fundamental. ${ }^{4}$

Spekulasi dengan margin trading memang dapat mendorong terjadinyareaksi pasar yang berlebihan (market overreaction). Para investor akan melakukanhal-hal yang mungkin tidak rasional terhadap hal-hal yang ada seperti menetapkanharga yang rendah untuk bad news dan akan menetapkan harga yang terlalu tinggiterhadap good news. Adanya rumor atau informasi yang dianggap buruk (badnews) tersebut menyebabkan investor melakukan aksi jual dengan cepat karenapanik terhadap harga sama akan semakin jatuh. Tindakan irrasional tersebutdilakukan pada investor untuk menghindari

${ }^{1}$ M. Fakhruddin dan M. Sopian Hadianto (2001), Perangkat dan Model Analisis Investasi Pasar Modal, Buku Satu (Jakarta: PT Elex Media Komputindo), p. ix

${ }^{2}$ Ekaningtyas Widiastuti dan Dwita Darmawati (2010), "Analisa Market Overreaction pada Saham LQ 45 di Bursa Efek Indonesia”, Jurnal Fokus Ekonomi, Vol. 9, No. 3, pp. 128-202.

${ }^{3}$ Iggi H. Achsien (2003), Investasi Syari'ah di Pasar Modal: Menggagas Konsep dan Praktek Manajemen Portofolio, Cet. Kedua (Jakarta: Gramedia Pustaka Utama), p. 63.

${ }^{4}$ ibid, p. 64. 
kerugian. ${ }^{5} \mathrm{Hal}$ ini justru akanmerugikan investor karena mereka melakukan keputusan transaksi terhadapsaham atau asset tanpa mengetahui nilai wajar yang sebenarnya.

Keinginan investor untuk mendapatkan return yang besar, seharusnya jugatidak terlepas dari satu hal yang selalu mengiringi return, yaitu risiko. Hal inidikarenakan risiko mempunyai hubungan positif dan linier dengan return yangdiharapkan dari suatu investasi. Semakin besar return yang diharapkan maka akansemakin besar pula risiko yang harus ditanggung investor.

Menurut analisis investasi modern, risiko dalam investasi tersebut dibagi 2yaitu risiko sistematik dan tidak sistematik. Risiko tidak sistematik adalah risikoyang disebabkan oleh faktor-faktor unik atau variabel tak tentu yang berdampakhanya pada suatu sekuritas dan dapat dihilangkan dengan melakukan diversifikasi.Sedangkan risiko sistematik adalah risiko yang mempengaruhi semua sekuritassehingga tidak dapat dihilangkan meskipun dengan diversifikasi, karenamenyangkut faktor-faktor yang mempengaruhi pasar secara umum sepertiperubahan tingkat bunga, fluktuasi valuta asing dan kebijakan pemerintah.Pengetahuan tentang risiko menjadi penting untuk diketahui dan dikuasai olehinvestor yang rasional maupun calon investor. ${ }^{6}$

Dalam pasar modal syari'ah, larangan syari'ah diatas mestidiimplementasikan dalam bentuk aturan main yang mencegah praktik spekulasi,riba, garar dan maysir. Investor dituntut untuk bersikap rasional denganmenghilangkan semua unsur ketidaktahuan yang dapat menyeret kepada perilakuterlarang. Mendasari keputusan investasinya pada informasi yang terpercayatentang faktor-faktor fundamental ekonomi dan risiko-risiko dalam perusahaan itusendiri melalui kajian yang seksama. Kegiatan investor seperti ini disebut rationalspeculation, dan para spekulan rasional inilah yang sesungguhnya mendorongterciptanya akumulasi kapital yang mendorong perekonomian secara makro,karena investasi setiap orang didasari pada pencapaian performa perusahaan.Perusahaan Tbk. dituntut efisien, profitable dan prospektif jika ingin menarik hatiinvestor di pasar modal. ${ }^{7}$ Dengan berbagai model valuation modern saat ini,investor dan pasar secara luas, memiliki pengetahuan tentang nilai sebuahperusahaan, sehingga saham-saham dapat diperjualbelikan secara wajar denganharga pasar.

Kehadiran Jakarta Islamic Index (JII) di tengah kancah pasar modalkonvensional yang kerap menghalalkan segala cara untuk mendapatkan returnyang besar, diharapkan dapat memberikan nuansa dan warna sendiri. Investoryang menanamkan modalnya pada perusahaan yang tergabung dalam JII harusmenyingkirkan tindakan irrasional dengan mengetahui seluk beluk perusahaandengan baik.

${ }^{5}$ A. Ardi, Kiryanto dan Amalia D (2008), Overreaksi Pasar terhadap Harga Saham Perusahaanperusahaan di Indonesia (Studi Kasus di Bursa Efek Indonesia), Simposium NasionalAkuntansi Pontianak, p. 30.

${ }^{6}$ Nurul Huda dan Mustafa Edwin Nasution (2005), Investasi pada pasar Modal Syari'ah (Jakarta: Kencana Prenada Media), p. 16.

7ibid, p. 79. 
Pada titik inilah seorang investor muslim sebaiknya mempelajari terlebihdahulu kondisi sebuah perusahaan sebelum memutuskan untuk membeli ataupunmenjual saham tersebut. Hal ini berdasarkan alasan bahwa nilai saham mewakilinilai perusahaan. Investor sering membandingkan antara harga saham dengan nilaiatau harga yang sebenarnya dari saham tersebut, sebelum memutuskan untukmembeli atau menjual suatu saham. Nilai sebenarnya (nilai intrinsik) ini seringjuga disebut sebagai nilai fundamental. Nilai fundamental dapat dihitung denganmenggunakan dua jenis analisa sekuritas yaitu analisa sekuritas fundamental dananalisas sekuritas teknikal. ${ }^{8}$ Data yang diperlukan jika menggunakan analisisfundamental adalah data yang berasal dari laporan keuangan perusahaan sepertiReturn on Asset (RoA), Return on Equity (RoE) dan faktor fundamental yang lain. Sedangkan pendekatan teknikal dilakukan dengan melalui metode peramalandengan memperhatikan grafik kecenderungan saham.

Penilaian kewajaran harga saham yang terbentuk di pasar modal olehinvestor dapat dilakukan dengan analisis fundamental, sedangkan risiko sistematik(market risk) dapat mengurangi tingkat keuntungan yang akan diperoleh investor.Tujuan dilakukannya analisis saham sendiri adalah untuk menilai apakahpenetapan harga saham suatu perusahaan ditawarkan secara wajar atau tidak.

Dalam kerangka inilah penelitian ini dilakukan, walaupun disadari bahwafaktorfaktor fundamental sangat luas dan kompleks cakupannya. Tidak hanyameliputi kondisi internal perusahaan (basic financial dan economic facts) saja,melainkan juga kondisi fundamental makro perusahaan yang berada di luarkendali perusahaan. Sedangkan faktor lain untuk mengakomodasi perubahankecenderungan pasar yang terjadi dimasukkan indeks beta sebagai indicator pengukuran risiko sistematik yang mencerminkan sensitivitas saham perusahaanterhadap indeks pasar.

Berangkat dari latar belakang tersebut, penulis tertarik untuk menelititentang pengaruh faktor fundamental dan risiko sistematik terhadap harga sahamdi pasar modal syari'ah (Studi Empiris JII di BEI Tahun 2007-2010).

\section{A. Penelitian Terdahulu}

\section{KAJIAN PUSTAKA}

Penelitian terkait pengaruh faktor fundamental dan risiko sistematik sudah cukup banyak dilakukan di Indonesia. Syahib Natarsyah melakukan penelitian pada tahun 2000 dengan judul "Analisis Pengaruh Beberapa Faktor Fundamental dan Resiko Sistematik terhadap Harga Saham (Kasus Industri Barang Konsumsi yang Go Public di Pasar Modal Indonesia)” dan hasilnya mengungkapkan bahwa faktor fundamental (Return on Asset (ROA), Debt to Equity Ratio (DER) dan Book Value (BV)) berpengaruh secara signifikan terhadap harga saham perusahaan kelompok industri barang konsumsi

\footnotetext{
${ }^{8}$ Jogiyanto (2003), Teori Portofolio dan Analisis Investasi, Ed. ketiga (Yogyakarta: BPFE), p. 25.
} 
yang go public di pasar modal. Sedangkan faktor fundamental yang lain (Dividend Payout Ratio (DPR)) tidak signifikan.?

Penelitian Njo Anastasia Yanny Widiastuty dan Imelda Wijiyant ${ }^{10}$ tentang pengaruh factor fundamental dan resiko sistematik terhadap harga saham properti di Bursa Efek Jakarta menunjukkan bahwa faktor fundamental (Return on Asset (ROA), Returnon Equity (ROE), Dividend Payout Ratio (DPR), Debt to Equity Ratio (DER), Book Value (BV)) dan risiko sistematik mempunyai pengaruh secara signifikan terhadap harga saham perusahaan properti secara bersama-sama. Sedangkan secara parsial hanya variabel BV yang mempunyai pengaruh yang signifikan terhadap harga saham perusahaan properti.

Zulkifli Harahap dan Agusni Pasaribu juga melakukan penelitian terkait topik diatas dengan judul "Pengaruh Faktor Fundamental dan Risiko Sistematik terhadap Harga Saham pada Perusahaan Manufaktur yang Terdaftar di Bursa Efek Jakarta”. Penelitian dilakukan pada seluruh perusahaan manufaktur yang terdaftar di BEJ sejak tahun 2002-2005 serta aktif menerbitkan laporan keuangan yaitu sebanyak 120 perusahaan. Dari hasil analisis yang dilakukan dengan bantuan SPSS 11.5, menunjukkan bahwa faktor fundamental dan risiko sistematik secara simultan mempengaruhi harga saham. Akan tetapi secara parsial hanya BookValue per Share (BVS) dan Beta saham yang berpengaruh secara signifikan terhadap harga saham, sedangkan Return on Asset (ROA) dan Debt to Equity Ratio (DER) tidak berpengaruh secara signifikan terhadap harga saham. ${ }^{11}$

Penelitian serupa hanya dengan periode pengamatan yang berbeda juga dilakukan oleh Destri Rusi Widiasari. Pengamatan dilakukan pada 32 perusahaan manufaktur yang terdaftar di Bursa Efek Indonesia (BEI) pada tahun 2003-2006. Teknik pengujian data menggunakan regresi linear sederhana untuk menguji secara parsial dan regresi linear berganda untuk menguji secara simultan dengan tingkat signifikansi $\alpha 5 \%$. Hasil penelitian menunjukkan bahwa factor fundamental dan risiko sistematik secara simultan mempengaruhi pergerakan harga saham, sedangkan secara parsial hanya ROA, DER dan Beta saham yang berpengaruh secara signifikan terhadap harga saham karena BVS tidak berpengaruh secara signifikan. ${ }^{12}$

9 Syahib Natarsyah (2000), "Analisis Pengaruh Beberapa Faktor Fundamental dan Resiko Sistematik terhadap Harga Saham (Kasus Industri Barang dan Konsumsi yang Go Public di Pasar Modal Indonesia)", Jurnal Ekonomi dan Bisnis Indonesia, Vol. 15, No. 3, Juli, 2000.

${ }^{10}$ Njo Anastasia, Yanny Widiastuty dan Imelda Wijiyanto (2003), "Analisis Faktor Fundamental dan Risiko Sistematik terhadap Harga Saham Properti di BEJ”,Jurnal Akuntansi dan Keuangan, Vol. 5, No. 2, pp. 123-132.

${ }_{11}$ Zulkifli Harahap dan Agusni Pasaribu (2007), "Pengaruh Faktor Fundamental dan Risiko Sistematik terhadap Harga Saham pada Perusahaan Manufaktur yang Terdaftar di Bursa Efek Jakarta", Mepa Ekonomi: Jurnal Magister Ilmu Ekonomi,Vol. 2, No. 1, pp. 68-77.

${ }^{12}$ Destri Rusi Widiasari (2009), Pengaruh Faktor Fundamental dan Risiko Sistematik terhadap Harga Saham pada Perusahaan Manufaktur yang Terdaftar di Bursa Efek Indonesia, dikutip dari http://repository.usu.ac.id/handle/123456789/4046, diakses pada 13 Maret 2012. 
Fitri Aulianisa: Pengaruh Faktor Fundamental...

Penelitian-penelitian terkait dengan pengaruh faktor fundamental dan risiko sistematik terhadap harga saham memang sudah banyak dilakukan dalam kurun waktu tertentu. Namun keterkaitan atau pengaruhnya sulit untuk diukur sehingga memiliki celah bagi penelitian lain untuk dilakukan. Apalagi penelitian-penelitian diatas hanya dilakukan di pasar modal konvensional tanpa melibatkan saham syari'ah yang tergabung di JII. Jika menilik karakteristik pasar modal syari'ah yang unik, hal ini memberikan kesempatan bagi penulis untuk melakukan penelitian terkait pengaruh faktor fundamental yang lebih kompleks beserta risiko sistematik terhadap harga saham syari'ah yang tergabung di JII selama kurun waktu 2007-2010. Dengan demikian dapat dijadikan sebagai bahan perbandingan apakah faktor fundamental dan risiko sistematik berpengaruh terhadap harga saham syari'ah maupun konvensional atau memiliki signifikansi pengaruh yang berbeda.

\section{B. Landasan Teori}

\section{Pasar Modal Syariah}

Istilah pasar modal seringkali disamakan dengan pasar uang, padahalkeduanya memiliki unsur yang secara substansial berbeda meskipun keduanyamerupakan bagian dari sistem pasar keuangan (financial market).

Pasar uang adalah sarana yang menyediakan pembiayaan jangka pendek(kurang dari satu tahun) dan tidak mempunyai tempat fisik seperti pasar modal.Pembiayaan dilakukan dengan didasari oleh pinjaman (loan) yang melayanibanyak pihak, seperti pemerintah, bank, perusahaan asuransi, dan lembagakeuangan lainnya. Sedangkan instrumen yang diperdagangkan antara lain suratberharga pemerintah (bill and notes), sekuritas badan-badan pemerintah, sertifikatdeposito, perjanjian imbal beli dan surat perusahaan (company commercial paper) yang berupa promes, aksep dan wesel. ${ }^{13}$

Sedangkan pasar modal adalah pertemuan antara pihak yang memilikikelebihan dana dengan pihak yang memerlukan dana dengan cara memperjualbelikan sekuritas untuk jangka panjang, dan dalam arti sempit merupakan pasaryang konkrit. Sebagaimana halnya pasar pada umumnya yang merupakan tempatpertemuan antara penjual dan pembeli, di dalam pasar modal yangdiperjualbelikan adalah dana atau modal dalam bentuk saham, obligasi ataupunbentuk yang lain. Tempat penawaran dan penjualan efek ini dilaksanakanberdasarkan bentuk institusi (lembaga) resmi yang disebut sebagai Bursa Efek. ${ }^{14}$

Sedangkan menurut Undang-Undang Pasar Modal (UUPM), pasar modal adalah kegiatan yang bersangkutan dengan penawaran umum dan perdaganganefek,

\footnotetext{
${ }^{13}$ Irsan Nasarudin dan Indra Surya (2004), Aspek Hukum Pasar Modal Indonesia, Ed. Pertama (Jakarta: Kencana), p. 19.

${ }^{14}$ Ridwan Khairandy (2010), Hukum Pasar Modal I, Cet. Pertama (Yogyakarta: FH UII Press), p. 3 .
} 
perusahaan publik yang berkaitan dengan efek yang diterbitkannya, sertalembaga dan profesi yang berkaitan dengan efek. ${ }^{15}$

Dari pengertian tersebut di atas dapat diketahui bahwa pasar modal syari'ahadalah pasar modal yang dijalankan dengan prinsip-prinsip syariah. Setiaptransaksi perdagangan surat berharga (sekuritas) di pasar modal dilaksanakansesuai dengan ketentuan syariat Islam. ${ }^{16}$ Ketentuan syariat Islam atau prinsipsyari'ah yang terkandung dalam pasar modal syari'ah berarti bahwapenyelenggaraan pasar modal syari'ah harus berdasarkan fatwa Dewan Syari'ahNasional Majelis Ulama Indonesia (DSN-MUI) maupun peraturan Bapepam-LKsepanjang tidak bertentangan satu sama lain.

Kegiatan di pasar modal syari'ah berkaitan dengan perdagangan suratberharga (efek syariah) yang telah ditawarkan kepada masyarakat dalam bentukpenyertaan kepemilikan saham atau penerbitan obligasi syari'ah. Menurut fatwaDSN No. 40/DSN-MUI/X/2003, pengertian efek syari'ah adalah efeksebagaimana dimaksud dalam peraturan perundang-undangan di bidang pasarmodal yang akad, pengelolaan perusahaan, maupun cara penerbitannya memenuhiprinsip-prinsip syari' ah. ${ }^{17}$ Sedangkan transaksi yang dilarang dalam pasar modalsyari'ah adalah transaksi yang mengandung unsur garar(ketidakpastian/uncertainty), maysir (bersifat judi) dan manipulasi.

\section{Saham sebagai Salah Satu Instrumen Investasi di Pasar Modal Syariah}

Saham merupakan surat berharga keuangan yang diterbitkan oleh suatu perusahaan sebagai salah salah satu alat untuk meningkatkan modal panjang. Para pembeli saham membayarkan uang pada perusahaan dan mereka menerima sertifikat saham sebagai tanda bukti kepemilikan mereka atas saham-saham yang dicatat dalam daftar saham perusahaan. Para pemegang saham dari sebuah perusahaan merupakan pemilik-pemilik yang disahkan secara hukum dan berhak untuk mendapatkan bagian dari laba yang diperoleh oleh perusahaan dalam bentuk deviden. ${ }^{18}$

\section{Analisis Fundamental dan Teknikal untuk Penilaian Harga Saham}

Analisis fundamental adalah teknik-teknik yang mencoba memperkirakan harga saham di masa yang akan datang dengan cara: ${ }^{19}$

$>$ Mengestimasi nilai-nilai faktor fundamental yang mempengaruhi harga saham di masa yang akan datang.

$>$ Menerapkan hubungan variabel-variabel tersebut hingga diperoleh taksiran harga saham.

Adapun terminologi "analisa teknikal" adalah terminologi yang kompleks untuk metode yang paling dasar dalam investasi. Secara sederhana, analisa teknikal adalah

${ }^{15}$ UU No. 8 Tahun 1995 Pasal 1 angka 13 tentang Pasar Modal.

${ }^{16}$ Abdul Manan (2009), Aspek Hukum dalam Penyelenggaraan Investasi di Pasar ModalSyariah Indonesia, Ed. Pertama, Cet. Kesatu (Jakarta: Kencana), p. 77.

${ }^{17}$ Burhanudin (2009), Pasar Modal Syari'ah, Cet. Pertama (Yogyakarta: UII Press) pp. 10-11.

${ }^{18}$ Abdul Manan, Aspek..., p. 93.

${ }^{19}$ Iggi A. Achsien, Investasi..., p. 55. 
studi harga dengan menggunakan grafik sebagai alat utama. Analisa teknikal merupakan suatu teknik analisa yang menggunakan data atau catatan mengenai pasar itu sendiri untuk berusaha mengakses permintaan dan penawaran suatu saham tertentu atau pasar secara keseluruhan. Pendekatan analisis ini menggunakan data pasar yang dipublikasikan, seperti: harga saham, volume perdagangan, indeks harga saham gabungan dan individu, serta faktor-faktor lain yang bersifat teknis. Oleh sebab itu, pendekatan ini juga disebut sebagai pendekatan analisis pasar (market analysis) atau analisis internal (internalanalysis). Asumsi yang mendasari analisis teknikal adalah: ${ }^{20}$

Terdapat ketergantungan sistematik (systematic dependencies) di dalam return yang dapat dieksploitasi ke return abnormal.

$>$ Pada pasar yang tidak efisien, tidak semua informasi harga masa lalu diamati ketika memprediksi distribusi return sekuritas.

Nilai suatu saham merupakan fungsi permintaan dan penawaran.

\section{Risk and Return}

Setiap keputusan investasi selalu menyangkut dua hal, yaitu risk and return. Risiko dapat diartikan sebagai ketidaktentuan atas investasi yang diperoleh terhadap imbal hasil, sehingga dapat disimpulkan bahwa risiko adalah penyimpangan yang terjadi antara actual return dari yang telah diperkirakan sebelumnya yaitu imbal hasil yang diharapkan (expected return). Risiko mempunyai hubungan positif dan linear dengan return yang diharapkan dari suatu investasi. Sehingga, semakin besar return yang diharapkan maka akan semakin besar pula risiko yang harus ditanggung oleh seorang investor. Dalam melakukan keputusan investasi pada sekuritas saham, return yang diperoleh bedasar dari dua sumber yaitu deviden dan capital gain. Sedangkan risiko investasi saham tercermin dari variabilitas pendapatan (return saham) yang diperoleh. ${ }^{21}$

\section{Koefisien Beta}

Beta merupakan suatu perhitungan guna mengukur volatilitas atau pengukur risiko sistematik, dimana pengertian volatilitas adalah sebagai fluktuasi dari suatu return suatu sekuritas dalam periode tertentu. Jika fluktuasi return sekuritas secara statistik mengikuti fluktuasi return pasar, maka beta dari sekuritas tersebut bernilai 1. Misalnya apabila return pasar naik sebesar 5\%, maka investor akan mengharapkan kenaikan return sekuritasnya sebesar 5\% pula. Menurut Jogiyanto, beta adalah pengukur risiko sistematik dari suatu saham yang mana tidak dapat dihindarkan meskipun investor melakukan diversifikasi. Risiko ini berkaitan dengan kondisi yang terjadi di pasar secara umum, misalnya perubahan ekonomi secara makro, risiko tingkat bunga, risiko politik, risiko inflasi, risiko nilai tukar dan risiko pasar. ${ }^{22}$

${ }^{20}$ Lani Salim (2003), Analisa Teknikal dalam Perdagangan Saham (Jakarta: PT Elex Media Komputindo), p. 2.

${ }^{21}$ Nurul Huda dan Mustafa Edwin Nasution, Investasi..., p. 14

${ }^{22}$ Jogiyanto, Teori..., p. 45 


\section{Hipotesis}

Hipotesis merupakan pernyataan atau dugaan yang bersifat sementara terhadap suatu masalah penelitian yang kebenarannya masih lemah sehingga harus diuji secara empiris. ${ }^{23}$ Dalam pembuatan hipotesis dalam penelitian ini, penulis mengacu dan memperhatikan hipotesis seerta hasil uji hipotesis dalam penelitian sebelumnya. Oleh karena itu, hipotesis dalam penelitian ini adalah adanya pengaruh yang signifikan antara faktor fundamental (DAR, ROA, NPM, EPS, PER) dan risiko sistematik (Beta) terhadap harga saham yang tergabung dalam JII di BEI tahun 2007-2010 baik secara parsial maupun simultan.

\section{METODE PENELITIAN}

\section{A. Sifat dan Jenis Penelitian}

Penelitian ini bersifat deskriptif analitik, yaitu penelitian yang menggambarkan dan menjelaskan variabel-variabel independen untuk menganalisis bagaimana pengaruhnya terhadap harga saham yang tergabung dalam JII selama periode penelitian. Sedangkan jenis dari penelitian ini adalah penelitian korelasional (correlational research), yaitu penelitian yang bertujuan untuk menyelidiki sejauh mana variasi-variasi pada suatu faktor berkaitan dengan variasi-variasi pada satu atau lebih faktor lain berdasarkan koefisien korelasi.65 Dalam penelitian ini, akan dikaji sejauh mana pengaruh faktor fundamental dan risiko sistematik sebagai variabel independen terhadap harga saham perusahaan yang tergabung dalam JII selama periode 2007-2010.

\section{B. Populasi dan Penentuan Sempel}

Populasi dalam penelitian ini adalah seluruh saham yang tergabung dalam Jakarta Islamic Index (JII) dan terdaftar di Bursa Efek Indonesia (BEI) selama tahun 20072010. Setiap satu tahun terdiri dari 2 semester dimana pada masingmasing semester terdapat 30 perusahaan yang diumumkan memenuhi criteria untuk listing di JII. Akan tetapi, pada semester pertama di tahun 2008 penulis tidak mendapati perusahaan yang listing di JII dikarenakan tidak tersedianya datadari Indonesia Stock Exchange sehingga mengurangi jumlah perusahaan yang menjadi populasi dalam penelitian ini. Sedangkan sampel dilakukan dengan pendekatan non probability samplingdengan metode purposive sampling, yaitu peneliti telah membuat kisi-kisi ataubatas-batas berdasarkan ciri-ciri subyek yang akan dijadikan sampel penelitian. ${ }^{24}$ Batasan yang diterapkan pada perusahaan yang akan dijadikan sampel adalah:

$>$ Tergabung dalam JII selama periode 2007-2010

> Menerbitkan laporan keuangan lengkap selama periode 2007-2010

$>$ Memiliki nilai EPS yang positif.

${ }^{23}$ Iqbal Hasan (2004), Analisis Data dengan Statistik, Cet. Pertama (Jakarta: PT Bumi Aksara), p. 31.

${ }^{24}$ Supardi (2005), Metode Penelitian Ekonomi dan Bisnis. Cet. Pertama (Yogyakarta: UII Press), p. 115. 


\section{Jenis dan Teknik Pengumpulan Data}

Data yang digunakan dalam penelitian ini adalah data sekunder, yaitu data yang diperoleh secara tidak langsung dari sumber (perusahaan) tetapi dari laporan keuangan perusahaan yang menerbitkan saham syari'ah yang tergabung dalam JII dan terdaftar di Bursa Efek Indonesia dari tahun 2007 hingga 2010.

Dalam penelitian ini, teknik pengumpulan data yang digunakan adalah: Pertama Studi Pustaka, yaitu mencari literatur yang relevan dengan topic penelitian diatas, yaitu terkait dengan investasi di pasar modal syariah, faktor fundamental dan risiko sistematik hingga penelitian-penelitianterkait yang pernah dilakukan sebelumnya. Kedua Dokumentasi, yaitu mencari dan mendapatkan data-data terkait perusahaan yang menjadi obyek penelitian. Dalam hal ini peneliti mencari dan mengumpulkan laporan keuangan perusahaan yang menjadi sampel penelitian dari pojok BEI di Fakultas Ekonomi Universitas Islam Indonesia dan harga saham harian individu dan JII dari situshttp://yahoofinance.com.

\section{Definisi Oprasional Variabel Dependen $(\mathrm{Y})$ dan Independen (X)}

Variabel dependen sering juga disebut sebagai variabel respons, output, kriteria atau variabel terikat yang merupakan variabel yang dipengaruhi data, karena adanya variabel bebas. ${ }^{25}$ Variabel dependen dalam penelitian ini adalah harga saham perusahaan-perusahaan yang tergabung dalam JII tahun 2007-2010.

Variabel independen atau sering juga disebut variabel stimulus, predictor dan antecedent merupakan variabel bebas yang menjadi sebab timbul atauberubahnya variabel dependen. Dengan demikian, variabel independen adalahvariabel yang mempengaruhi. ${ }^{26}$

\section{E. Teknik Analisis Data dengan Regresi Linier Berganda, Uji Asumsi Klasik dan Koefisien Determinasi (R Square)}

Teknik analisis data yang digunakan adalah regresi linier berganda (multiple regression), yaitu teknik mengukur besarnya pengaruh variabel independenterhadap variabel dependen. ${ }^{27}$ Variabel independen dalam penelitian ini adalahDAR, ROA, NPM, EPS, PER dan risiko sistematik (Beta), sedangkan variable dependen adalah harga saham. Adapun uji asumsi klasik ini perlu dilakukan agar tidak terdapat masalah normalitas, multikolinieritas, heteroskedastisitas dan autokorelasi.

Koefisien determinasi adalah suatu nilai yang menggambarkan besaran perubahan atau variasi dari variabel dependen bisa dijelaskan oleh perubahan atau variasi dari variabel independen. Dengan mengetahui nilai koefisien determinasi, peneliti dapat menjelaskan kebaikan dari model regresi dalam memprediksi variabel dependen.

\footnotetext{
${ }^{25}$ Sugiyanto (2004), Analisis Statistika Sosial, Ed. Pertama, Cet. Pertama (Malang: Bayumedia), p. 13.

${ }^{26}$ ibid.p. 12.

27 Syamsul Hadi (2006), Metodologi Penelitian Kuantitatif untuk Akuntansi dan Keuangan (Yogyakarta: Ekonisia), p. 159.
} 
Terdapat dua jenis koefisien, yaitu $\mathrm{r}$ koefisien determinasi biasa dan koefisien determinasi disesuaikan (Adjusted $\mathrm{R}$ Square). Pada regresi berganda, penggunaan koefisien determinasi yang telah disesuaikan lebih baik dalam melihat seberapa baik model dibandingkan koefisien determinasi. Koefisien determinasi disesuaikan merupakan hasil penyesuaian koefisien determinasi terhadap tingkat kebebasan dari persamaan prediksi. Hal ini melindungi dari kenaikan bias atau kesalahan karena kenaikan dari jumlah variabel independen dan kenaikan dari jumlah sampel. ${ }^{28}$

\section{F. Pengujian Hipotesis melalui Uji Parsial (Uji T) dan Uji Simultan (Uji F)}

Uji Parsial digunakan untuk membuktikan hipotesis kedua digunakan uji t dengan tujuan mengetahui pengaruh dari masing-masing variabel bebas terhadap variabel terikat. Dengan uji t dapat diketahui apakah variabel faktor fundamental secara parsial berpengaruh signifikan terhadap variabel harga saham atau tidak. Uji Simultan digunakan untuk menunjukkan apakah semua variabel bebas yang dimasukkan dalam model memiliki pengaruh secara serentak/bersama-sama terhadap variabel terikat. Dengan melakukan Uji F dapat diketahui apakah variabel independen yang terdiri dari DAR, ROA, NPM, PER, EPS dan Beta secara serentak berpengaruh secara signifikan terhadap harga saham atau tidak.

\section{HASIL DAN PEMBAHASAN}

\section{A. Deskripsi Objek Penelitian}

1. PT Kalbe Farma Tbk

PT Kalbe Farma Tbk (dikenal dengan sebutan Kalbe dengan kode saham KLBF) menjadi perusahaan publik pada tahun 1991 dengan mendaftarkan sahamnya pada BEI. Kalbe memfokuskan bisnisnya pada 4 bisnis yang relative memberikan kontribusi yang seimbang, yaitu resep obat-obatan (berkontribusi 25\%), produk kesehatan konsumer (berkontribusi 17\%), produk nutrisi (berkontribusi 22\%) serta distribusi dan pengemasan (berkontribusi 36\%).

Didukung oleh 15.000 karyawan, yang termasuk 4000 pemasar professional yang tersebar di seluruh kepulauan Indonesia, Kalbe mempertahankan jangkauan lebih dari $70 \%$ dokter umum, 90\% dokter spesialis, 100\% rumah sakit, 100\% apoteker di seluruh Indonesia untuk pasar resep obat-obatan dan $80 \%$ untuk pasar produk kesehatan dan nutrisi. ${ }^{29}$

Kinerja fundamental dan beta sekuritas KLBF selama periode pengamatan tergambar pada tabel dibawah ini:

${ }^{28}$ Purbayu Budi Santosaa dan Ashari (2005), Analisis Statistik dengan Microsoft Excel \& SPSS (Yogyakarta: Penerbit Andi), p. 114.

${ }^{29}$ http://www.kalbe.co.id/about/brief/diakses pada 21 Maret 2012 
Fitri Aulianisa: Pengaruh Faktor Fundamental...

Tabel 9 Kinerja Fundamental dan Beta Sekuritas KLBF

\begin{tabular}{|l|r|r|r|r|r|r|}
\hline Tahun & \multicolumn{1}{|l|}{ DAR } & \multicolumn{1}{l|}{ ROA } & \multicolumn{1}{l|}{ NPM } & \multicolumn{1}{l|}{ EPS } & \multicolumn{1}{l|}{ PER } & \multicolumn{1}{c|}{ BETA } \\
\hline 2007 & $21.8 \%$ & $13.7 \%$ & $10.1 \%$ & 112 & 11.3 & -0.07 \\
\hline 2008 & $23.8 \%$ & $12.4 \%$ & $9.0 \%$ & 117 & 34.2 & 0.77 \\
\hline 2009 & $26.1 \%$ & $14.3 \%$ & $10.2 \%$ & 97 & 13.4 & 0.42 \\
\hline 2010 & $17.9 \%$ & $18.3 \%$ & $12.6 \%$ & 137 & 23.7 & 1.14 \\
\hline $\begin{array}{l}\text { Rata-rata } \\
\text { Sektoral* }\end{array}$ & $34.6 \%$ & $10.3 \%$ & $8.7 \%$ & 151.91 & 20.7 & 0.57 \\
\hline
\end{tabular}

Sumber: laporan keuangan tahun 2007-2010 yang diolah dengan Ms. Excel

*Rata-rata sektoral merupakan rata-rata kinerja sektor industri barangkonsumsi (sektor asal KLBF), terkecuali rata-rata beta yang merupakan rata-ratabeta sekuritas KLBF.

Tabel diatas menunjukkan sejumlah deskripsi sebagai berikut:analisis struktur hutang: tabel tersebut menunjukkan bahwa rasio DARKLBF mengalami peningkatan pada 3 tahun pertama dalam periode pengamatansehingga struktur modal perusahaan dibiayai sebanyak $26.1 \%$ yang ada diatasrata-rata DAR sektoral yang bernilai $22.9 \%$. $\mathrm{Hal}$ ini mengindikasikan perusahaanagresif dalam menggunakan hutang untuk membiayai struktur modalnya. Disatusisi hal ini dapat membebani perusahaan karena besarnya biaya hutang yang harusditanggung setiap tahunnya, dan disisi lain ada kemungkinan perusahaan sedangmelakukan ekspansi usaha sehingga membutuhkan modal yang lebih. Meskipundemikian, rasio DAR yang sempat meningkat ini kembali menurun pada tahun2010 sebesar 5\% menjadi 17.9\%. Agresifitas perusahaan dalam menggunakanhutang masih dalam tahap normal karena tidak terjadi secara berkelanjutandimana KLBF masih berupaya untuk menurunkan ketergantungannya terhadaphutang, dan jika dikomparasikan dengan rata-rata DAR sektoral yang berkisar34.6\%, maka rasio DAR KLBF masih ada jauh dibawah itu.

Analisis profitabilitas: rasio ROA KLBF cenderung menunjukkan kenaikanmeskipun pada tahun 2008 sempat menurun sebesar 1.1\%, namun tahuntahunberikutnya rasio ini terus meningkat meskipun tidak signifikan. Jika dilakukananalisis komparasi, maka rasio ROA ini selalu ada diatas rata-rata ROA sektoralyang mencapai $10.3 \%$. Kenaikan rasio ini perlu diapresiasi mengingat manajermasih mampu mengelola secara efisien total aktiva perusahaan sehinggamenghasilkan laba dan menjaga stabilitas finansial perusahaan agar selaluprofitable.

Analisis efisiensi biaya: rasio NPM cenderung stabil, dalam artian tidakmengalami lonjakan yang tajam ataupun penurunan yang drastis. Rasio inimenunjukkan bahwa manajemen cukup efektif dalam menghasilkan laba bersihdan hal ini perlu untuk ditingkatkan atau minimal dipertahankan. Investor tentulebih memilih emiten yang rasio profitabilitas atau efisiensi biayanya melebihirata-rata sektoral karena lebih 
menjanjikan dan profitable, sehingga jika menilikanalisis historis ataupun komparasi, KLBF layak untuk dijadikan sarana investasi.

Analisis market performance: nilai EPS dari tahun ke tahun juga mengalamistagnasi, dalam artian meskipun ada kenaikan namun tidak signifikan sehingganilai EPS selalu ada dibawah rata-rata EPS sektoral yang bernilai Rp 151.91selama 4 tahun periode pengamatan. Sedangkan jika dilihat dari PER, hanya tahun2007 dan 2009 yang berada di bawah PER sektoral yang berkisar 20.7 kali. PERtertinggi ada pada tahun 2008 yang mencapai 32.4 kali. Meskipun pada akhirnyatahun pada tahun 2010 nilai PER menurun hingga mencapai 23.7 kali, namuntetap ada diatas rata-rata PER sektoral. Hal ini menunjukkan antusiasme investorpada saham KLBF sehingga PER terhitung cukup tinggi.

Analisis beta sekuritas: beta sekuritas KLBF pada 3 tahun pertama diperiode pengamatan menunjukkan angka kurang dari 1 yang berarti saham KLBFbersifat defensive yang mengindikasikan saham tersebut kurang peka terhadapperubahan return pasar sehingga pada titik ini risiko sistematik yang ditanggunginvestor terhitung kecil karena risiko sekuritas ada dibawa rata-rata pasar.Sedangkan tahun 2010 nilai beta meningkat menjadi 1.14 atau jika dibulatkansama dengan 1. Hal ini menunjukkan bahwa fluktuasi return KLBF secarastatistik mengikuti fluktuasi return pasar, sehingga jika return pasar mengalamiperubahan sebesar satu persen baik naik ataupun turun, maka return saham KLBFjuga akan bergerak sama besar mengikuti return pasar.

\section{PT Tambang Batubara Bukit Asam Tbk}

PT Tambang Batubara Bukit Asam Tbk (dengan kode saham PTBA)merupakan perusahaan yang bergerak di bidang penambangan batubara yangawalnya diprakarsai oleh pemerintahan kolonial Belanda. Bersamaan denganprogram pengembangan keamanan energi nasional, pada tahun 1990 perusahaanini ditugaskan oleh pemerintah untuk mengembangkan bisnis briket batubara.Pada tanggal 23 Desember 2002, perusahaan ini menjadi perusahaan terbuka(publik) yang terdaftar di BEI. ${ }^{30}$ Sedangkan kinerja fundamental dan beta sekuritas PTBA dapatdigambarkan pada tabel berikut:

\section{Tabel 10 Kinerja Fundamental dan Beta Sekuritas PTBA}

\begin{tabular}{|r|l|l|l|r|r|l|}
\hline \multicolumn{1}{|l|}{ Tahun } & DAR & ROA & NPM & EPS & PER & BETA \\
\hline 2007 & $33.2 \%$ & $28.0 \%$ & $23.7 \%$ & 741 & 9.3 & 1.35 \\
\hline 2008 & $28.4 \%$ & $33.8 \%$ & $30.5 \%$ & 1,184 & 14.6 & -0.08 \\
\hline 2009 & $28.4 \%$ & $33.8 \%$ & $30.5 \%$ & 1,184 & 14.6 & 1.08 \\
\hline 2010 & $26.2 \%$ & $23.0 \%$ & $25.4 \%$ & 872 & 26.3 & 0.86 \\
\hline $\begin{array}{l}\text { Rata-rata } \\
\text { Sektoral }\end{array}$ & $33.4 \%$ & $10.1 \%$ & $11.9 \%$ & 503.34 & 14.9 & 0.81 \\
\hline
\end{tabular}

${ }^{30}$ http://ptba.co.id/en/about/historydiakses pada 21 Maret 2012 
Fitri Aulianisa: Pengaruh Faktor Fundamental...

Sumber: laporan keuangan tahun 2007-2010 yang diolah dengan Ms. Excel

* Rata-rata sektoral merupakan rata-rata kinerja fundamental sector pertambangan yang merupakan asal sekuritas PTBA, terkecuali rata-rata betayang merupakan rata-rata beta tahunan PTBA

Tabel diatas dapat dideskripsikan sebagai berikut: analisis struktur hutang: analisis historis PTBA menunjukkan bahwa rasioDAR mengalami tren penurunan setiap tahun. Jika pada tahun 2007 rasio inihampir sama dengan rata-rata rasio hutang sektoral yang berkisar 33.4\%, makatahun 2007 rasio ini berhasil turun 7\% hingga menjadi 26.2\%. Meskipun tidakserendah rasio hutang perusahaan serupa yang ada dalam satu sektor, namunpenurunan rasio DAR ini menunjukkan bahwa PTBA berusaha mengurangiketergantungan terhadap hutang dan hal ini mengindikasikan kemandirianperusahaan yang semakin percaya diri menjalankan aktivitas bisnsnya. Disisi lain,hal ini menguntungkan bagi investor karena risiko yang ditanggung akan semakinberkurang jika suatu saat terjadi goncangan akibat krisis keuangan dan labaoperasi yang dihasilkan tidak akan tergerus karena menanggung beban biayahutang yang terlalu besar.

Analisis profitabilitas: rasio ROA dalam tabel diatas terlihat cukup stabil.Meskipun tejadi kenaikan atau penurunan selama 4 tahun periode pengamatan, namun nilai rasio ini tetap ada diatas rata-rata ROA sektoral yang berkisar 10.1\%.Hal ini menunjukkan bahwa PTBA mampu menjaga stabilitas finansialnya agarselalu dalam kondisi stabil dan profitable dengan melakukan efisiensi penggunaanaktiva perusahaan agar menghasilkan laba yang optimal.

Analisis efisiensi biaya: rasio NPM dalam tabel diatas juga terlihat cukupstabil. Kenaikan atau penurunan yang terjadi berkisar 5-7\% dalam rentang 20-30\% selama 4 tahun periode pengamatan, namun tetap berada diatas rata-rataNPM sektoral yang bernilai $11.9 \%$. Stabilitas finansial ini harus dipertahankanoleh perusahaan mengingat rasio ini menjadi pertimbangan bagi investor untukmenanamkan modalnya. Manajer harus mampu melakukan efisiensi biayasehingga secara profitabilitas perusahaan secara keseluruhan dapat dioptimalkanmeningkatkan kinerja perusahaan dimata investor.

Analisis market performance: nilai EPS pada tabel diatas menunjukkanangka yang cukup fantastis karena ada dalam rentang Rp 700- Rp 1,100 yangberarti selalu ada diatas rata-rata EPS sektoral yang hanya berkisar Rp 503.34.Investor dalam jangka panjang tentu akan diuntungkan dengan earning yang stabilini, apalagi nilai PER PTBA juga sukup stabil meskipun pada tahun 2010,perbandingan antara harga saham dan earning yang diberikan mencapai 26.3 kaliatau 11.4 kali lipat lebih besar dibanding rata-rata PER sektoral yang mencapai14.9 kali. Hal ini mengindikasikan minat investor pada saham PTBA cukup tinggijika dibandingkan dengan nilai EPSnya.

Analisis beta sekuritas: analisis historis menunjukkan bahwa pada tahun20092010 nilai beta PTBA kurang dari 1 yang menunjukkan bahwa sahamtersebut bersifat defensive atau kurang peka terhadap perubahan pasar sehinggamemiliki risiko dibawah rata-rata pasar. Sedangkan pada tahun 2007 dan 2009nilai beta cenderung sama dengan 
1 yang berarti fluktuasi return saham PTBAsecara statistik akan mengikuti fluktuasi return pasar. Hal ini menunjukkanbahwa setiap satu persen perubahan return pasar baik naik ataupun turun, makaakan diikuti sama besarnya oleh return saham PTBA. Meskipun demikian, rataratabeta tahunan menunjukkan saham PTBA bersifat defensive sehingga amandan layak untuk menjadi wadah investasi karena risiko sistematik yangditanggung oleh investor tidak terlalu tinggi karena ada dibawah rata-rata pasar.

\section{B. Analisis dan Pembahasan}

Adalah suatu kenyataan bahwa perkembangan Islamic Finance merupakan representasi masuknya hukum-hukum religius dalam wilayah kehidupan komersial. Islamic Finance menantang hukum komersial sekuler yang dipresumsikan lebih efisien dan superior, menantang hukum komersial yang memisahkan dirinya dari pertimbangan religious dan kepatuhan atas ajarannya. ${ }^{31}$ Lahirnya pasar modal syari'ah pun tak lepas dari adanya hukum-hukum syariah yang berlaku didalamnya, demi kepentingan orang-orang yang melakukan transaksi didalamnya.

Dalam hal pasar modal, kurangnya pengetahuan atau informasi (jahalah, ignorance) pada pihak yang melakukan kontrak dapat dikategorikan sebagai transaksi yang mengandung garar dan jelas harus dihindari. Untuk itulah analisis fundamental dibutuhkan sebagai salah satu sarana untuk mengenali emiten yang akan menjadi wadah investasi.

Deskripsi obyek penelitian yang telah dipaparkan oleh penulis sebelumnya dapat memberikan sedikit gambaran tentang kinerja fundamental 8 perusahaan yang menjadi sampel penelitian. 8 perusahaan tersebut selama 4 tahun periode pengamatan (20072010) selalu konsisten terdaftar dalam JII yang merupakan indeks yang mewakili keberadaan pasar modal syari'ah di Indonesia. 8 perusahaan tersebut berasal dari 5 sektor yang terdaftar di Daftar Efek Syariah yaitu sector pertambangan yang diwakili oleh 3 emiten (ANTM, INCO dan PTBA), pertanian yang diwakili oleh 1 emiten yaitu AALI, sektor industri dasar dan kimia yang diwakili oleh INTP, industri barang konsumsi yang diwakili 2 emiten (KLBF dan UNVR) dan sektor infrastruktur, utilitas dan transportasi yang diwakili oleh TLKM.

Berdasarkan analisis deskriptif yang didasarkan pada kinerja fundamental (individu maupun sektor) dan risiko sistematik yang dilakukan pada 8 sampel tersebut, dapat disimpulkan bahwa seluruh sampel terhitung layak dan aman untuk dijadikan sarana investasi. Hal ini berdasarkan analisis profitabilitas dan efisiensi biaya yang ratarata ada diatas rata-rata sektoral masing-masing, hal ini mengindikasikan bahwa emiten tersebut memiliki kinerja atau performance yang bagus.

Jika dilihat dari nilai EPS, meskipun beberapa emiten memiliki nilai EPS yang ada dibawah rata-rata sektor masing-masing, seperti INCO, KLBF dan ANTM, namun secara keseluruhan kedelapan memiliki nilai EPS yang stabil dan selalu bernilai positif sehingga investor tidak dirugikan. Sedangkan jika dilihat dari analisis beta sekuritas,

${ }^{31}$ Iggi A. Achsien, Investasi ..., p.19. 
Fitri Aulianisa: Pengaruh Faktor Fundamental...

maka kedelapan sampel tersebut memiliki rata-rata beta dibawah atau kurang dari 1 yang mengindikasikan saham-saham tersebut kurang peka terhadap pergerakan atau perubahan pasar. Hal ini menguntungkan bagi investor yang tergolong risk averter atau investor yang tidak suka terhadap risiko karena risiko yang ditanggung jika menginvestasikan dananya pada emiten yang memiliki nilai beta kurang dari 1 berada dibawah rata-rata pasar.

Namun jika dilihat sari struktur hutang, ada 2 emiten yang masih memiliki struktur hutang yang tinggi, bahkan cenderung diatas rata-rata rasio hutang sektoralnya, seperti UNVR dan TLKM. Hal ini perlu diwaspadai meskipun pada hakikatnya tingkat hutang tersebut masih bercampur dengan hutang yang berbasis bunga. Penggunaan hutang yang terlalu tinggi akan menempatkan emiten dalam kondisi tidak stabil karena tingkat financial risk yang tinggi sekaligus mengurangi kemandirian emiten dalam menjalankan aktivitas bisnis serta dalam pengambilan keputusan.

Pada titik ini seharusnya kriteria $45 \%$ batas maksimal untuk struktur hutang di pasar modal syari'ah di Indonesia betul-betul diterapkan dengan membuat aturan baru untuk memuat rasio hutang non ribawi pada laporan keuangan. Dengan demikian dapat dilihat rasio hutang yang murni, bukan yang berbasis ribawi apakah memenuhi standar maksimal yang ditetapkan atau tidak. Hal ini juga untuk memudahkan calon investor yang akan menginvestasikan dananya pada emiten terkait. Sedangkan keputusan investasi saham dari sisi analisis laporan keuangan adalah sebagai berikut:

$>$ Memilih perusahaan dengan nilai ROA yang tinggi, yang berarti efektifdalam mengelola asset untuk menghasilkan laba.

$>$ Memilih perusahaan dengan nilai NPM yang tinggi, yang berarti efisiendalam mencetak laba.

$>$ Memilih perusahaan dengan nilai DAR yang rendah atau medium, yangberarti pasif dalam menggunakan hutang.

$>$ Memilih perusahaan dengan nilai PER yang rendah atau dibawah rataratasektoral. Dengan kata lain adalah memilih perusahaan dengankinerja yang baik namun memiliki nilai PER yang rendah.

Menilik landasan keputusan investasi saham tersebut, maka penulis dapatmerekomendasikan saham AALI dan INTP sebagai sarana berinvestasi. Meskipunpada kenyataannya kedelapan emiten memiliki kinerja fundamental yang baik,namun penulis cenderung pada 2 emiten tersebut karena merujuk pada rasio DARyang rendah, rasio ROA dan NPM yang stabil berada diatas rata-rata sektoral dannilai PER yang rendah atau dibawah rata-rata sektoral. Meksipun demikian, tidakmenutup kemungkinan untuk dilakukan analisis yang lain untuk menentukankeputusan investasi saham tersebut.

Jika dikomparasikan dengan hasil uji statistik dapat dilihat bahwa seluruhfaktor fundamental dalam penelitian ini (DAR, ROA, NPM, EPS dan PER) danrisiko sistematik (Beta) secara bersama-sama berpengaruh secara signifikanterhadap harga saham dimana EPS memiliki kontribusi yang paling besar terhadapperubahan harga saham. Hal ini sesuai dengan uji parsial yang menyatakan bahwaEPS berpengaruh 
secara signifikan terhadap harga saham, begitu juga denganPER. Jika secara parsial hanya EPS dan PER yang berpengaruh secara signifikanterhadap harga saham, maka investor perlu mencermati dan menganalisis 2 faktortersebut sebelum memutuskan untuk berinvestasi pada emiten tertentu. Nilai EPSyang tinggi mengindikasikan tingginya earning yang diperoleh oleh investorsetiap tahunnya, akan tetapi berbeda dengan nilai PER yang seringkali berbedadengan teori yang seharusnya.

Nilai PER yang tinggi seringkali dijadikan indikator tingginya minatinvestor terhadap saham terkait, padahal tidak semua emiten yang memiliki nilaiPER yang tinggi memiliki kinerja fundamental yang sehat. Jika merujuk kembalikepada defisini PER yang merupakan perbandingan antara harga saham denganEPS, maka seharusnya saham-saham dengan PER yang rendah sangat menarikuntuk dibeli dan sebaliknya, akan tetapi kenyataannya tidak demikian. Olehkarena itu investor yang jeli dan memiliki tujuan jangka panjang tidak bias langsung memutuskan keputusan investasinya hanya pada faktor PER ataupunEPS untuk menilai harga saham tersebut overpriced, underpriced ataupun normal.Investor perlu tetap menganalisis faktor-faktor lain untuk menganalisa kinerjafundamental sebuah emiten.

Hal penting yang perlu digaris bawahi adalah bahwa harga sahamdipengaruhi oleh banyak faktor dan analisis fundamental hanyalah salah satu carauntuk memprediksi faktor-faktor yang berpengaruh terhadap pergerakan hargasaham. Analisis fundamental merupakan cara yang paling mudah dilakukan untukmenghindari unsur ketidaktahuan investor tentang saham sebuah emiten yangakan dibeli ataupun sebaliknya. Dengan menghilangkan unsur jahalah ini,seorang investor akan terbebas dari garar, maysir ataupun tindakan lain yangtidak dibenarkan oleh syariah Islam. Investasi yang dilakukan oleh seoranginvestor muslim diharuskan terbebas dari unsur-unsur haram tersebut.

Landasan hukum prinsip keuangan Islami tersebut akan memberikan jalanbagi para investor yang ingin menggunakan prinsip-prinsip Islam dalam menilaisecara kritis emiten-emiten yang tersedia di pasar modal syariah. Dengan penilainkritis tersebut pada investor tersebut tidak lantas langsung menerima daftar emitenyang terdaftar di JII sekalipun karena tetap tidak menutup kemungkinan untukmelakukan perbaikanperbaikan dan inovasi yang memberikan tawaran baru demikesejahteraan dan kemanfaatan yang lebih luas.

\section{PENUTUP}

Berdasarkan deskripsi dan analisis yang telah dipaparkan sebelumnya, maka dapat diambil beberapa kesimpulan bahwa berdasarkan hasil uji parsial (Uji t), dari 6 variabel independen (factor fundamental dan risiko sistematik) hanya variabel EPS (X4) dan PER (X5) yang berpengaruh secara signifikan terhadap harga saham dengan nilai signifikansi masing-masing 0.000 dan 0.013 dengan $\alpha$ 5\%, sedangkan variabel independen lain (DAR, ROA, NPM dan Beta) tidak memiliki pengaruh yang signifikan terhadap perubahan/pergerakan harga saham. Sedangkan hasil uji simultan (Uji F) menunjukkan bahwa faktor fundamental (DAR, ROA, NPM, EPS, PER) dan risiko 
Fitri Aulianisa: Pengaruh Faktor Fundamental...

sistematik (Beta) secara simultan berpengaruh secara signifikan terhadap pergerakan atau perubahan harga saham perusahaan yang listing di JII selama 2007-2010 dengan nilai signifikansi 0.000 atau lebih kecil dari $\alpha 5 \%$.

Demi kemajuan pengembangan pasar modal syariah di Indonesia, maka ada saran yang diajukan, yaitu (i) perlu diterapkan aturan mengenai pencantuman proporsi hutang non ribawi yang tidak bercampur dengan hutang yang berbasis ribawi agar tidak terjadi ambiguitas dalam menentukan struktur hutang terhadap modal agar tidak melebihi batas maksimal 45\%; (ii) diclosure laporan keuangan hendaknya dilakukan lebih tepat waktu sesuai akhir periode tertentu (triwulanan, semesteran, tahunan) sehingga memudahkan penelitian ataupun analisis yang membutuhkan data laporan keuangan tersebur; (iii) untuk penelitian yang akan datang, diperlukan analisis yang berbeda untuk meneliti terkait harga saham ataupun faktor tertentu yang terkait saham seperti analisis teknikal ataupun model analisis rasio keuangan untuk melengkapi analisis fundamental yang berbasis rasio keuangan ini. Diharapkan hasil penelitian akan lebih komprehensif dan lebih memudahkan investor dalam mengambil keputusan investasi.

\section{DAFTAR PUSTAKA}

Achsien Iggi H. (2003), Investasi Syari'ah di Pasar Modal: Menggagas Konsep dan Praktek Manajemen Portofolio, Cet. Kedua. Jakarta: Gramedia Pustaka Utama.

Al-Quran Karim dan Terjemahan Artinya, 1999. Diterjemahkan oleh Zaini Dahlan,Yogyakarta: UII Press.

Anastasia, Njo, Yanny Widiastuty dan Imelda Wijiyanto (2003), "Analisis Faktor Fundamental dan Risiko Sistematik terhadap Harga Saham Properti di BEJ", Jurnal Akuntansi dan Keuangan, Vol. 5, No. 2, Nopember 2003.

Ardi, A., Kiryanto dan Amalia D. (2008), "Overreaksi Pasar terhadap Harga Saham Perusahaan-perusahaan di Indonesia (Studi Kasus di Bursa Efek Indonesia)", Makalah Simposium NasionalAkuntansi,di Pontianak 2008.

Burhanudin (2009), Pasar Modal Syari'ah, Cet. Pertama (Yogyakarta: UII Press).

Fakhruddin, M. dan M. Sopian Hadianto (2001), Perangkat dan Model Analisis Investasi PasarModal, Buku Satu. Jakarta: PT Elex Media Komputindo.

Hadi, Syamsul (2006). Metodologi Penelitian Kuantitatif untuk Akuntansi dan Keuangan Yogyakarta: Ekonisia.

Harahap, Zulkifli dan Agusni Pasaribu (2007), "Pengaruh Faktor Fundamental dan

Risiko Sistematik terhadap Harga Saham pada Perusahaan Manufaktur yang Terdaftar di Bursa Efek Jakarta”, Mepa Ekonomi: Jurnal Magister Ilmu Ekonomi, Vol. 2, No. 1, pp. 68-77.

Hasan, Iqbal (2004), Analisis Data dengan Statistik, Cet. Pertama. Jakarta: PT Bumi Aksara.

http://www.kalbe.co.id/about/brief/diakses pada 21 Maret 2012.

http://ptba.co.id/en/about/historydiakses pada 21 Maret 2012. 
Fitri Aulianisa: Pengaruh Faktor Fundamental...

Huda, Nurul dan Mustafa Edwin Nasution (2005), Investasi pada pasar Modal Syari'ah.Jakarta: Kencana Prenada Media.

Jogiyanto (2003), Teori Portofolio dan Analisis Investasi, Ed. Ketiga. Yogyakarta: BPFE UGM.

Khairandy, Ridwan (2010), Hukum Pasar Modal I, Cet. Pertama. Yogyakarta: FH UII Press.

UU No. 8 Tahun 1995 Pasal 1 angka 13 tentang Pasar Modal.

Manan, Abdul (2009), Aspek Hukum dalam Penyelenggaraan Investasi di Pasar ModalSyari'ahIndonesia, Ed. Pertama, Cet. Kesatu. Jakarta: Kencana.

Nasarudin, Irsan dan Indra Surya (2004), Aspek Hukum Pasar Modal Indonesia, Ed. Pertama (Jakarta: Kencana).

Purbayu, Budi Santosa dan Ashari (2005), Analisis Statistik dengan Microsoft Excel \& SPSS.Yogyakarta: Penerbit Andi.

Salim, Lani (2003), Analisa Teknikal dalam Perdagangan Saham.Jakarta: PT Elex MediaKomputindo.

Sugiyanto (2004), Analisis Statistika Sosial, Ed. Pertama, Cet. Pertama. Malang: Bayumedia.

Supardi (2005), Metode Penelitian Ekonomi dan Bisnis. Cet. Pertama. Yogyakarta: UII Press.

Syahib, Natarsyah (2000), “Analisis Pengaruh Beberapa Faktor Fundamental dan Resiko Sistematik terhadap Harga Saham (Kasus Industri Barang dan Konsumsi yang Go Public di Pasar Modal Indonesia)", Jurnal Ekonomi dan Bisnis Indonesia, Vol. 15, No. 3, Juli 2000.

Widiasari, Destri Rusi (2009), "Pengaruh Faktor Fundamental dan Risiko Sistematik terhadap Harga Saham pada Perusahaan Manufaktur yang Terdaftar di Bursa Efek Indonesia”, Skripsidikutip dari http://repository.usu.ac.id/handle/123456789/4046 diakses pada 13 Maret2012.

Widiastuti, Ekaningtyas dan Dwita Darmawati (2010), "Analisa Market Overreaction pada Saham LQ45 di Bursa Efek Indonesia”, Jurnal Fokus Ekonomi, Vol. 9, No. 3, pp. 128-202. 